\title{
SCHOOL-AGE CARE, AN IDEOLOGICAL CONTRADICTION
}

\author{
PROBLEMS \\ OF EDUCATION \\ IN THE $21^{\text {st }}$ CENTURY \\ Volume 48, 2012 \\ 45
}

\author{
Peter Karlsudd \\ Linnaeus University, Sweden \\ E-mail: peter.karlsudd@Inu.se
}

\begin{abstract}
In the doctoral dissertation "Children with intellectual disability in the integrated school-age care system" the extent and goal fulfilment of after-school recreation centre activities in 19 Swedish municipalities were studied. The study gave high marks to these centres for integrating intellectually disabled children into their activities. The empirics of the dissertation revealed, however, a number of warning signals, which indicated an increase in offering "special solutions" to these children.

This article will contain a comparison between the study from 1999 and the one carried out in the spring of 2011. The two studies have followed the same question construction in order to achieve a comparison over time. The aim of study, focusing on children received into schools for the intellectually disabled was to evaluate to what extent integrated activities occurred and to look for factors with a positive impact on the quality of those after-school activities which gathered children from these and compulsory schools in the same groups.

On the basis of the comparison made between the 12 years that have passed from the earlier to the later study, it must be regretfully concluded that segregated activities have gained a firm hold on the activities of after-school recreation care centres.
\end{abstract}

Key words: after-school activities, inclusion, integrated, intellectual disability, school-age care system.

\section{Introduction}

The child care system in Sweden has been subject to considerable change during the 1990s. The municipalities' possibilities to create their "own operations" in combination with a declining economy have been a strong reason for organisational and operational changes. Many municipalities have been forced to implement savings measures, which have had a negative impact on operations. Cutbacks in general operations can lead to a general decline in quality and an increased need of special solutions for the group, which is particularly vulnerable, the children in need of special support.

After-school teaching is a relatively young profession that has undergone major changes over the years. The required education has been reformed, the governing documents replaced, the number of children in after-school activities has increased and the after-school teachers have expanded duties. 20 years ago after-school care activity focused mainly on care and nursing. Now the professional role and approach seems more appropriate for the school culture (Calander, 1999; Gustavson, 2003; Haglund, 2004).

The emphasis during the last four decades has been that Swedish after-school care should be open to all children. Those children who require special support in their development should be given priority placement in an integrated organization. The idea behind giving intellectually disabled children a place in school-age care is to stimulate them through the positive environment offered by the after-school centre. For a great many children the generally good quality of afterschool activities makes the chief contribution (Karlsudd, 2003; Karlsudd, 2007). 
PROBLEMS

OF EDUCATION

IN THE $21^{\text {st }}$ CENTURY

Volume 48,2012

In international agreements, the compulsory school ordinance and curricula it is stated that segregation in school and school-age childcare should be avoided. Notwithstanding this, pupils are being regularly placed in special types of school, where the teaching is mostly done in special groups in special localities and with special teachers. After-school centres, however, have rarely made a distinction between normal and special activities. The clear objective of pedagogical and activity goals has been that every child should be included in joint activities. In the beginning of 2000 clear come signals from the National Board of Health and Welfare suggesting that a number of municipalities gave clear evidence of gearing towards segregated after-school activities, i.e. activities in which solely children with intellectual disability are registered.

According to the Swedish National Agency for Education, the number of pupils in the compulsory school for the intellectually disabled increased by over 50 percent between 1995 and 2006. This increase has not been proportional to variations in the number of pupils in the compulsory school; nor can it be related to any established increase in the number of children with intellectual disabilities in the population at large. The Swedish Schools Inspectorate has therefore found it necessary to make a close scrutiny of how the registration for the school for the intellectually disabled is done. A large number of the reports, which are supposed to form the basis for receiving children into these schools, have turned out to contain serious deficiencies. The result of this scrutiny is alarming in that it reveals a lack of competence in all parts of the reports (Skolinspektionen, 2011). There is strong evidence of wrong diagnoses and unmotivated registration for segregated activities and it is an obvious risk of ambitions for normalisation and integration being lost. For all these reasons mentioned it is interesting to use an earlier study (Karlsudd, 1999) and its questions as starting points for following up the development of activities in the last 12 years.

What has happened to Swedish after-school recreation centres during a period with such a dramatic registration increase in schools for the intellectually disabled? Has this care type managed to resist segregating forces and keep its inclusive activities? The following section will contain a comparison between the study from 1999 and the one carried out in the spring of 2011 (Karlsudd, 2011).

\section{Methodology of Research}

The two studies have followed the same question construction in order to achieve a comparison over time. The first study came to focus on a group of children in need of special support, that is children from the special schools' junior and middle schools attending integrated day-centre establishments. The study was carried out in 19 municipalities and included 96 handicapped children at 73 institutions. Follow-up interviews took place at 14 institutions in six municipalities. The aim of the 1999 study, was to evaluate to what extent integrated activities occurred and to look for factors with a positive impact on the quality of those after-school activities which gathered children from these and compulsory schools in the same groups. The information was taken from questionnaires answered by those responsible for the organization, after-school care personnel and parents. The steering documents "Pedagogical program for daycentres" (1988:7) and "Child care is for all children" (1991:1) formed a basis for the design of the questionnaires. The questions were divided into twelve areas, in all of which there was an obvious connection between the questions and the goals set for activities. To supplement the questionnaire study a number of follow-up interviews were made with the staff. The distribution of the study group with regard to sex, age, school type and school child care corresponded well with the overall distribution then applying in the country.

At the time of the implementation of the study (Karlsudd, 1999) $87 \%$ of children in schools for the intellectually disabled were placed in integrated after-school care in Sweden. 
As for preschools, over 90 percent of all intellectually disabled children were placed in groups together with the non-intellectually disabled, while only 16 percent of the former were integrated into compulsory school classes during school hours. Against this background school-child care appeared as a last resort or sanctuary of inclusiveness, where intellectually disabled children formed part of groups with the non-intellectually disabled.

To create a picture of the current situation a new study was conducted in 2011 after exact the same units comprised by the 1999 study.

\section{Research Results}

When the study was conducted in 1998 there were three segregated after-school recreation centres in the 19 municipalities. The total number of intellectually disabled children in segregated activities was 12. At the corresponding study in the spring of 2011 there were eleven segregated after-school centres with 57 children from the school for the intellectually disabled (Table 1). This means an increase of 266 percent of the number of segregated centres and a 375 percent increase of the number of intellectually disabled children in segregated activities. The total number of after-school care children did not increase notably during the period in question.

At the 1998 study 96 children from schools for the intellectually disabled were registered at 73 integrated after-school centres. In the study made in 201190 children from such schools were registered at 40 integrated centres (Table 1).

Table 1. The relation between integrated and segregated after-school care activities in 19 municipalities in 1998 and 2011.

\begin{tabular}{|l|c|c|}
\hline A study conducted in 19 municipalities & 1998 & 2011 \\
\hline Number of segregated after-school centres & 3 & 11 \\
\hline $\begin{array}{l}\text { Number of children from schools for the intellectually disabled in } \\
\text { segregated after-school centres }\end{array}$ & 12 & 57 \\
\hline Number of integrated after-school centres & 73 & 40 \\
\hline $\begin{array}{l}\text { Number of children from schools for the intellectually disabled in } \\
\text { integrated after-school centres }\end{array}$ & 96 & 90 \\
\hline
\end{tabular}

On the basis of the question construction used in the earlier study interviews were made with 12 recreational pedagogues who were working or had previously been working with intellectually disabled children integrated in after-school care centres. The questions investigated the leisure pedagogues opinion of the goal fulfillment for the integrated children. The strategy behind the sampling of recreational pedagogues was to achieve a broad representation. The follow-up study may offer important clues to how the development has proceeded during the 13 years that have passed since the first study was completed (Karlsudd, 2009; Karlsudd, 2011).

The method used for the interview and transcripts can be likened to that Kvale (1997) names "purport concentration". Long statements are condensed into shorter statements, in which the essential meaning of what was said rephrased in a few words. "This process reduces major interview texts to brief and concise formulations. The result could be clearly divided into four sections namely, organization and resources; fulfilling; responsibility and planning and competence. 
PROBLEMS

OF EDUCATION

IN THE $21^{\text {st }}$ CENTURY

Volume 48,2012

\section{1) Organization and resources}

The children from schools for the intellectually disabled who were now placed in integrated activities form part of considerably larger groups. The drastic increase in the number of segregated after-school care children is quite apparent. In the earlier study of 1998 the staff of the after-school centres suggested a number of possible improvements in information, support and supervision in connection with placing the children from the schools for the intellectually disabled. A fairly great number of the staff considered the efforts insufficient. Nevertheless, the acclimatization worked well as a rule, largely because of the staff's positive attitude to the placement.

In the 2011 follow-up study the staff reported that children from the school for the intellectually disabled more seldom took part in the after-school activities. This corresponds well with the information presented in Table 1 . The acclimatization is described as problem free, since the intellectually disabled children used to go along with their classmates in preschool activities. For a few after-school centres it is natural to include the intellectually disabled in their activities. These centres are infused with distinctly expressed fundamental values and with an attitude that may be defined as an inclusive culture. This staff believes that the parents of the intellectually disabled appreciate that their children attend ordinary after-school care. The management, too, looks upon inclusiveness as an important principle for the activities.

At other after-school care centres the idea of inclusiveness is far from prevalent. In the interviews the staff of these centres give the impression of having a fairly normative view of children from the school for the intellectually disabled. Words like "very special, fuzzy cases, typical intellectually disabled children, feather-brained" are some of the expressions that may be heard in their descriptions of the children.

The staff contact with children and parents was on the whole very satisfactory in the earlier study. Contacts with the schools for the intellectually disabled were less so as compared with the contacts with the compulsory school. Today the contacts seem better in comparison with the earlier study. They are now considered satisfactory in relation to both types of school One explanation may be that the activities now lie closer to one another in the physical sense.

\section{2) Chances of fulfilling after-school centre goals for children with intellectual disabilities}

In the earlier study the staff assessed the chances of fulfilling the goals and tasks of afterschool recreation centres with regard to the intellectually disabled as somewhat less than for other children. The explanation given was that such children required special efforts and made a much higher demand on the competencies of the staff. Nonetheless, the situation of these children in integrated activities was fairly good. The parent group appreciated these activities very highly. Still, there were quite a few children involved in the activities for which the goals were not satisfactorily met.

According to the follow-up study the recreation pedagogues found it difficult to reach the goals for every child, since too many children are registered. Some interviewees considered it more difficult to integrate other groups of children, like those with neuropsychiatric impairment, since such children often need greater efforts, while the special resources required seldom accompany the placement. Resources for intellectually disabled children are generally linked to school activities but are non-existent in the after-school centres. Hence it is hard for the staff to find enough time and create the necessary peace and quiet.

The earlier study showed that the internal environment was important for goal fulfillment. In several municipalities after-school recreation activities had been moved to school premises, which were mostly described as being less adapted for the purpose. The lack of small rooms was mentioned. No reduction of the number of children in the groups was made to counterbalance the presence of children from the school for the intellectually disabled. 
Today after-school centre units have substantially more children in their groups than previously. There are examples of groups with more than 60 children. The centres are as a rule located in school premises, which are described as crowded and with sound levels that are hard to adjust. Some recreational pedagogues find it hard to adapt activities to a child in need of special support when they have so many children to consider. If a child, for example, finds in difficult to watch pictures on the walls, everyone has to stay in a stripped-down internal environment. Only a few centres have succeeded in adapting toys and environment to suit all children.

\section{3) Division of responsibility, planning and competence development}

In the earlier study the importance of having an extra person employed for the placement was emphasized. In the organizations that lacked such resources there were many who felt in need of staff reinforcement. Changes in the economic terms stamped the activities in the years preceding the millennium shift and several centres lost the extra staff originally recruited for the individual child.

There are clear indications in the follow-up study of a dwindling number of assistants. The division of responsibility for work with the intellectually disabled children looks different. Some after-school centres have extra staff tied to the child as well as clear rules of procedure. The staff is concerned that an assistant who directs all the energy towards one special child may affect this child's sense of belonging with other children negatively. There are many who underline the important function of other children in supporting the integrating processes. Shared responsibility is thus the rule of the thumb.

It was established in the earlier study that planned and structured observation seldom occurred. The same goes for planning that focused on the intellectually disabled child. The explanation given was lack of time. These children took part in all activities without any special measures taken. Still, some of those interviewed thought that adaptations of activities on behalf of the intellectually disabled children often benefited other children as well. In assessing the situation of the former the staff relied largely on spontaneous observations. Planning and implementation of measures were often based on unsystematized or unstructured experiences. Although the placement of the child was said to affect the planning of activities it did not push the other children in the group into the background.

In this respect the later study corresponds well to earlier results. There are also examples of more focused planning and documentation, perhaps thanks to special needs teachers in the compulsory school. Activities in schools for the intellectually disabled have approached those of after-school recreation centres, since school and centre are located in the same premises, which increases the accessibility to supervision and special competencies.

According to the earlier study, a large part of the staff was dissatisfied with the knowledge they had acquired in their basic education. Since very little time was set aside for continuing professional development it happened frequently that the staff tried to increase their knowledge in their spare time. A few work teams developed their competencies in giving guidance, seeing the great need for guidance and support. Some of the interviewees in the later study claim that the education received, if any, focuses on school activities. As far as guidance is concerned it may have improved through approaching the activities of schools.

\section{4) Attitude to integration/inclusiveness}

The earlier study confirmed that the parents of intellectually disabled children experienced the child's placement in integrated activities as very positive. This was of special importance since this has been often the longest time the child joined a group of its own age from the 
PROBLEMS

OF EDUCATION

IN THE $21^{\text {st }}$ CENTURY

Volume 48,2012

50

compulsory school. Very few of the other parents and children experienced the integration negatively. One explanation may be that most of the children and adults had previously met intellectually disabled children in integrated preschool activities. Integration was thus seen as something natural.

Even in the follow-up study the staff claimed that most of the other parents experienced the integrated activities positively. The staff has a good contact throughout with the parents of the intellectually disabled children. The other children who have been together with these in preschool are described by the staff as being more tolerant. This may be evidence that a more accepting attitude to handicapped people de facto grows out of such meetings. Naturally, there are also some who find it problematic to work in integrated activities.

In the earlier study integration as a principle was well anchored among the staff. Among the circumstances that the staff considered most important for a successful integration were sufficient personnel resources or a care assistant.

In the follow-up study there were many among the staff who stated clearly that integration/ inclusiveness was a good principle for after-school care activities, but there were also those that were not as convinced. Some thought that it depended on the individual child whether it would qualify for taking part in inclusive activities. As the terms obviously change from one year to another the staff then wish to reconsider the principle. Several interviewees express their support for the traditional school for intellectually disabled children. Many, however, find the economic terms unsatisfactory. There is a willingness to integrate but the resources available put a stop to this type of activity. All in all, quite a few positive comments on the advantages of integration are manifested in the interviews with the staff.

\section{Discussion}

It seems as though after-school recreation centres have lost a great deal of their responsibility for including all children in joint activities. The increasing segregation within school is exactly replicated in the activity of the after-school centres. Obviously, the same division obtains between children in the centres as in the school organization. Some centres may be described as focusing on relations, with a staff viewing children's dissimilarities as a resource, whereas in others the dissimilarities are looked upon as a deficiency, which should be better compensated for in separated activities. Quite clearly, the economy and the restructuring of activities have played a decisive role in this context. The size of the child group and changes in the attitude to the teaching mission are some of the reasons for this. On the basis of the comparison made between the 12 years that have passed from the earlier to the later study, it must be regretfully concluded that segregated activities have gained a firm hold on the activities of after-school recreation care centres.

\section{Conclusions and Implications}

That the establishments' quality is to a large extent dependent on the conditions surrounding the personnel's situation is a kind of decision-making where the pedagogical implications have their base. The atmosphere among personnel has proved to have considerable importance in the fulfillment of the objectives and it is important that extra resources are reserved for this and that the personnel continuously check that these are used in the right way.

School-age child care system maintain an integration tradition which must be developed. The establishments have many valuable educational aspects. It is therefore necessary that these experiences come to the fore in the cooperation now taking place with schools and that the carriers of tradition are accorded real influence in future work. There has obviously been a low level of activity during the last ten years regarding research into the integration of children and 
young people with mental handicaps. The child care system includes many of these children and its work deserves greater attention. Allocating resources for research into this area is, therefore,

logical. As the last integration sanctuary no longer functions there is a need for comprehensive measures to restore the original ideas and ideals.

\section{References}

Calander, F. (1999). Från fritidens pedagog till hjälplärare. Fritidspedagogers och lärares yrkesrelation $i$ integrerade arbetslag. Uppsala universitet.

Gustavsson, J. (2003). Integration som text, diskursiv och social praktik. (Göteborg Studies Educational Sciences 199) Göteborg: Acta universitatis Gothoburgensis.

Haglund, B. (2009). Fritid som diskurs och innehåll. En problematisering av verksamhet vid"afterschoolprograms" och fritidshem. Pedagogisk forskning i Sverige, (1), (22-44).

Karlsudd, P. (1999). Särskolebarn i integrerad skolbarnsomsorg. Malmö: Institutionen för pedagogik, Lärarhögskolan i Malmö.

Karlsudd, P. (2003). Children with intellectual disability in the integrated school-age care system. Interaction, 16 (2).

Karlsudd, P. (2007). The "Narrow" and the "Wide" activity: The circumstances of integration. The International Journal of Disability, Community \& Rehabilitation, 6 (1).

Karlsudd, P. (2011). "Integreringsreservatet"- finns det kvar? Klerfelt, A. \& Haglund, B. (Ed.). Fritidspedagogik - Fritidshemmets teorier och praktiker. Stockholm: Liber.

Kvale, S. (1997). Den kvalitativa forskningsintewjun. Lund: Studentlitteratur.

Socialstyrelsen. (1991). Barnomsorgen är för alla barn (Allmänna råd från socialstyrelsen). Stockholm.

Socialstyrelsen (1998). Pedagogiskt program för fritidshem. Stockholm: Allmänna förlaget.

Skolinspektionen (2011). Särskolan. Granskning av handläggning och utredning inför beslut om mottagande. Stockholm: Skolinspektionen.

Advised by Judita Stankutè, SMC “Scientia Educologica”, Lithuania

Received: September 24, 2012

Accepted: November 08, 2012

Peter Karlsudd

Professor, Linnaeus University, SE-391 82 Kalmar, Sweden.

E-mail: peter.karlsudd@Inu.se

Website: http://nu.se/employee/peter.karlsudd?|=en 